Mariola Walczak-Mikołajczakowa Adam Mickiewicz University in Poznań mawal@amu.edu.pl ORCID: 0000-0001-8871-9738
Data przesłania tekstu do redakcji: 10.09 .2020

Data przyjęcia tekstu do druku: 27.10.2020

\title{
From the History of the Bulgarian Animalistic Lexis. Names of Animals in the Oldest Bulgarian Translation of Aesop's Fables
}

\begin{abstract}
Aвstract: Walczak-Mikołajczakowa Mariola, From the History of the Bulgarian Animalistic Lexis. Names of Animals in the Oldest Bulgarian Translation of Aesop's Fables. "Poznańskie Studia Slawistyczne" 20. Poznań 2021. Publishing House of the Poznań Society for the Advancement of the Arts and Sciences, Adam Mickiewicz University, pp. 21-35. ISSN 2084-3011.

Bulgarian works of a non-religious nature began to be written in the $19^{\text {th }}$ century. They popularized a specific vision of a new literary language and contained suggestions of terms from various fields. Sophronius, bishop of Vratsa belonged to the group of writers who significantly influenced the shape of New Bulgarian literary language. By translating Aesop's fables into a language understandable to Bulgarians, he laid the foundations of Bulgarian animalistic terminology. The author analyses 66 names of animals contained in the fables translated by Sophronius, indicates their origin and the reasons for using a specific term. She further examines which of these terms are still used, and which have become archaisms or have survived only in folk dialects.
\end{abstract}

KeYwords: Aesop's fables; animalisms; development of the lexical system; New Bulgarian literary language

At the very beginning of the $19^{\text {th }}$ century, when Bulgarian authors turned their attention to Aesop's oeuvre and began working on translations of his fables, the literary Bulgarian language was far from being normalized. It was then that the period of the National Revival began, which was supposed to bring a reflection on the need of developing a standard language for the whole nation only in the next decade. The codification of language norms took place even later - after regaining independence (1878), i.e. after several decades of stormy discussions. Throughout this time, individual writers used to write in the languages they knew best, i.e. in the Church Slavonic language traditional for Bulgarian writing, in their 
preferred dialects, spoken in a limited area, or - most often - using a mixture of Orthodox Church language and vernacular.

A linguistic mosaic is characteristic of nineteenth-century Bulgarian literature, and the language of almost every work was a specific proposition of the shape of the literary Bulgarian language. The process of lexical enrichment of the language proceeded with the greatest intensity in the period after the liberation, when significant changes took place in the socio-economic and intellectual life of the country, and institutions focused on working on the New Bulgarian literary language started operating. "През този период книжовният език се превръща не само в средство, но и в оръдие за развитие на науката, културата и просветата" - a famous lexicographer Todor Boyadzhiev (Бояджиев, 1986, 37) wrote. However, before this happened, individual writers began taking up non-religious topics and creating educational works, thus expanding the lexical resources of the Bulgarian language. The use of specific lexical means by the most famous and respected writers had a significant impact on the later language standard developed in the course of long discussions (Вълчев, 2009).

Therefore, special attention should be paid to the oldest works of a non-religious character, which popularized a specific vision of the language and, as it were, suggested terms from various fields. Among the group of writers, who significantly influenced the language of the first half of the nineteenth century, was undoubtedly Stoyko Vladislavov - Bishop of Vratsa, known as Sophronius of Vratsa, author of the first Bulgarian translation of Aesop's fables.

Aesop's fables, due to the characters appearing in them, are usually called animal fables. Their titles themselves usually contain at least one name of the animal, so by translating 144 works $^{2}$ of a semi-legendary Greek writer in 1802, Sophronius laid the foundations for the development of animalistic terminology (Walczak-Mikołajczakowa, 2009, 15-40). Another, anonymous translator, who in 1812 translated 120 fables from the Modern Greek collection of Joanis Patusas followed his example. However,

1 "During this period, language became not only a means, but also a tool for the development of science, culture and education" (translated by M.W.-M.).

${ }^{2}$ Sophronius wrote a total of 147 fables, but the three other fables, included in the collection, are not works by Aesop. 
they remained in manuscript and never gained a wider audience, as there was a significant limitation in language translation. Today, this anonymous manuscript is the subject of research by a few historians of the language, who see in it only a proposal to use the local dialect of the Kiustendil area as a literary language (Ничев, 1961). Bulgarian names of animals do not have a separate dictionary, and for linguists they are interesting mainly from the point of view of their etymology or as a component of phraseologisms (v. е.g. Александрова, 1993; Зидарова, 1997; Недкова, 2005, Нанкинов, 2010). ${ }^{3}$ There was also no single, generally accepted term for the names of animals. In Polish linguistics, they are most often referred to as animalisms, but there are also terms such as: zoo lexemes, zoo appellatives and faunisms (Szerszunowicz, 2014), which in turn are in vain to be found in Bulgarian studies. The descriptive term названия на животните is most often used there because, as it seems, the terms зооном and зоолекса, proposed by Todor Balkanski and Kiril Cankov (Балкански, Цанков, 2010, 150), were not widely used, although these, in turn, became popular in the research of Russian and Serbian linguists. On the other hand, the term zoonim is widely used in all languages - this, however, refers to the names of animals given to them by humans, not to their appelatives. In this article, therefore, the clear terms animalisms and faunisms will be used as synonyms for the term animal names.

The analysis will cover the animalisms appearing in the oldest translation, i.e. in the collection of fables written by Sophronius of Vratsa, which are part of the so-called The second Vidinski collection - a compilation manuscript, containing, apart from the fables, also short didactic dialogues based on the works of the ancient writers and other moralizing works. The Sophronius manuscript was not published until the $20^{\text {th }}$ century, but literary historians believe that it nevertheless had a great influence on many Bulgarian authors. Ivan Radev, author of The History of Bulgarian Literature of National Revival period assesses this work as follows:

Макар и останал неотпечатан, той [Втори видински сборник] оказва значително влияние върху българската литература през следващите десетилетия, като

${ }^{3}$ In Poland, comparative studies on animalistic phraseologisms from various Slavic and non-Slavic languages are particularly popular (v. e.g. the works of J. Szerszunowicz, J. Anusiewicz, A. Nowakowska and others). 
жанрьт на кратките дидактични форми е доразвит от автори като Петър Берон, Неофит Бозвели, Неофит Рилски, Райно Попович, Константин Огнянович ${ }^{4}$ (Радев, 2007, 110).

As a commentary to the above quotation, let us add that three of the authors mentioned by Radev (Beron, Bozveli, Popovich) also dealt with fable-writing, and their works clearly refer to the translations of Sophronius (Walczak-Mikołajczakowa, 2009).

In the Sophronius translation, there are a total of 66 names of animals belonging to different classes and families. The largest group consists of mammals (28 names), and birds (21 names). Arthropods (insects, arachnids, and bugs among them) are represented by 8 names, there are 5 reptiles and amphibians, fish occur under two names, two different names also refer to snails, one to a crustacean and one to a primitive tissue free aquatic animal called a sponge. Some of them have been accepted by the creators of the New Bulgarian literary language and are still used today, others have been forgotten, and still some others have been preserved only in folk dialects.

Among the names of mammals, we can find representatives of all the above-mentioned categories. The name acıаnь 'lion' is one of the archaisms that have not found a place in the new literary Bulgarian region. This name, borrowed from the Turkish language (Tur. aslan), appears in the text of as many as 13 fables, the lion of which is the main character, e.g. Acrans и жава, ААсица и аслань, Аслань и ме, вє, , ь. It was widely known and used, as evidenced not only by the possibility of making derivatives from it (v. дслалска кожа, дсланските погте), but also the fact that it was used by other writers for a long time after Sophronius, including Ivan Vazov. The dictionary of rare and obsolete words (Илчев, 1974) under the entry аслан notes such examples taken from the works of Vazov as "Хората от едно правят сто, от мравката аслан!; Изви кривака, свали го бърже / с ръка юнашка, с сила асланска" (Илчев, 1974, 20). Later, when the Bulgarian language began to be cleansed of orientalisms, аслан gave way to

\footnotetext{
${ }^{4}$ Although it was not published, The Second Vidinski Collection had a great influence on the Bulgarian literature for the next decades, and short didactic forms were continued and developed by authors such as Petar Beron, Neophit Bozveli, Neophit of Rila, Rayno Popovich, Konstantin Ognyanovich.
} 
the Slavic (already used in Old Bulgarian writing) name $л ъ в$. A testimony to the process of changing lexemes and its long duration is the dialogue cited in the same dictionary taken from the work of Angel Karaliychev (1902-1972), the author of fairy tales, legends and stories for children, where аслан is used by a representative of the older generation: "В София имаше един мост с четири големи аслани от желязо. Стоят ли още асланите? Стоят. Дядо Петко се успокои, като разбра, че львовете са на мястото си" (Илчев, 1974, 20).

Borrowings from Turkish are also names such as: катьрь (contemporary: катър 'hybryd of a donkey and a mare', from Turkish katır) and маїмвнь (contemporary маймуна 'monkey', from Turkish myjmun), which have been preserved in the language to this day. It is worth noting that the Bulgarian language distinguishes between the names катър 'a hybrid of a stallion and a donkey' and муле 'a hybrid of a donkey and a mare', while in the Polish language only one word is used muł (from Lat. mūlus) (Boryś, 2008, 342).

In the translations of Sophronius, we can also find the Turkish word ать, which usually means 'riding horse.' This noun meaning of the word am was used e.g. in folk songs, where such horses were usually described as beautiful and well-fed. In the fable Mагарzы сирєчь: катzірь Sophronius uses the word ать as an adjective, focusing precisely on the connotations associated with it: "Како не є отєць мои магарzы, ами й конь ать, почто аъь все на Neго прихичамь."

To define a beaver Sophronius used the word касторхи derived from Greek. However, realizing that this name is not widely known, the fable $W$ касторХи began with an explanation: "КасторХи та є є, инь скоть сась

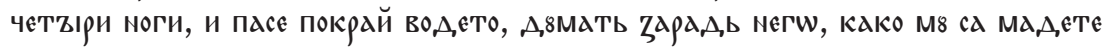
исц'ьлитєлки." By paying attention to the healing power of beaver testicles, he probably aroused the interest of readers in this rare animal, which, however, did not result in consolidation of the Greek name in Bulgarian. Among the names of mammals borrowed from Greek, we can also find the noun камила, which means 'a camel', which has found a permanent place in the literary Bulgarian language replacing the Old Bulgarian name вєльвлж,, $\mathrm{Z}$ noted among others in the Suprasl Code.

A frequent hero of Aesop's fables is a donkey - in the translation of Sophronius of Vratsa магарzі. The noun мazape is used to this day, not 
only in Bulgarian, but also in Macedonian (мazape), Serbian (магараи) and Croatian (magarac), although its etymology causes difficulties for researchers. Most linguists (Miklosich, Berneker, Mladenov) derive it from

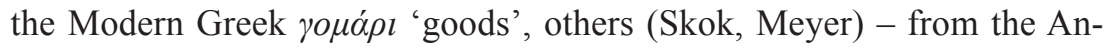
cient Greek $\sigma \alpha \dot{\gamma} \mu \alpha$ 'saddle’ (Георгиев, 1986, 598-600).

In relation to two animals, Sophronius uses archaic names - the oldest dictionary collecting Bulgarian vocabulary treats them as obsolete (Геров,

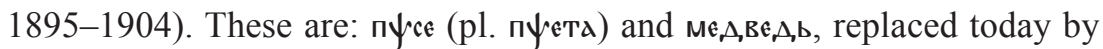
куче (Геров, 1897, 437) and мечка (Геров, 1899, 62). Particularly interesting here is the name пұck, written with the Greek letter $\psi$ (psi), that is the way it was popularized in the $17^{\text {th }}$ century by the Damaskins authors. Currently, it has narrowed its meaning and refers only to a large, dangerous dog. $M_{\mathfrak{\epsilon}_{,}, \mathrm{B}, \mathrm{B}, \mathrm{b}} \mathrm{b}$, on the other hand, was replaced with various lexemes (including мечек, медун), of which мечка had the widest range and was introduced to general Bulgarian.

Among the remaining animalisms relating to mammals, the descriptive way of naming the bat is worth noting: мочма мзішка фарковита (lit. 'night flying mouse'). In Nayden Gerov's dictionary we find the name that is already in use today: прилепь. However, the author cites a number of synonyms (вечерно пиля, въшерь, каральпь, лиликана, лилякъ, люлячи, ношно пиля), which means that at the end of the $19^{\text {th }}$ century, many dialectal variants of the name were still used at the end of the $19^{\text {th }}$ century (Геров, 1901, 27). Perhaps, aware of this diversity, Sophronius chose a descriptive name.

He did not seem to have any hesitations while writing about the dolphin (А,єлфина), although it is certainly not a widely known animal. Knowledge about its belonging to mammals is not common. Sophronius did not need it anyway, he could just see it as a sea animal, because in the fable, the main character of which is a dolphin, it is about his pursuit of some undefined fish (pzisa) and the death of both of them after going ashore.

The remaining animalisms refer to commonly known, domesticated or wild animals, but typical of Bulgarian fauna, therefore Sophronius had no problems naming them in a way that was understandable to most recipients. These names, also present in contemporary literary Bulgarian, differ only in the way of writing, which in some cases reflects the etymology of vowels (ZаАкь) and the reduced pronunciation of some of them (квш8тA). 
In addition, Sophronius does not use the letter $\mathrm{z}$, hence the soft yer always appears in a speech, regardless of the character of the final consonant, and the $\mathrm{z}$ inside a word is written in a vocalized form, i.e. o (волкь) or as a (картица). The following names of animals can be included in this group (in the order of their appearance in the texts): хасъІца (лисица), кобєль (козел), ұлатка (златка - 'pine marten'), мұішка (мишка), котка (котка), волкь (вълк), овца (овца), глигань (глиган - 'boar'), картица (къртица - 'mole'), квшвта (кошута -'doe'), рогдчь (рогач - here meaning 'deer'), ZаАКь (заек), конь (кон), свина (свиня), к8чка (кучка), кобєАь (козел), воль (вол).

The extensive group of bird names is very diverse. Sophronius uses the name птици for them, but also the more general name фарковатъітє га,Аини ('flying creatures'), which could refer to all animals that move with wings, although in the fable in which it was used (Павнь и мочмзий врамь) it refers only to the gathering of birds that have congregated gathered for the election of a king. Among the characters of fables, there are both domesticated, farmed and wild birds. The first group seems not to be troublesome - the translator used commonly used names of the most popular birds, such as: пєтеגь ('rooster'), кокошка / кокоша ('hen'), гвска ('goose').

The names of wild birds are more numerous and varied. Among them there are the same names as today: domestic pigeons (гол8вь, гол8вица), eagle (орєль), swallow (Аастовица), magpie (сврака), swan (АєБє, , $)$ ), raven (гарвань) and even a peacock (павнь). The name of the crane герань (со. жерав) can be included among archaisms and dialectisms at the same time. The faunism repan (borrowed from the Gr. $\gamma \varepsilon \rho \alpha v o ́ s$ ) used by Sophronius has survived to this day only in dialects and in the metaphorical, narrow, technical meaning of 'well with a crane' (hence, among others, геранска вода 'well water'). The name of a hawk А, ггань (tur. doğan), borrowed from the Turkish language, is also an archaism. In the literary Bulgarian language it was replaced with the Slavic lexeme ястреб, and доган is known today thanks to the name of one of the politicians. ${ }^{5}$ The dialectisms, however, include the name of the partridge юрбий (contemporary яребийа).

${ }^{5}$ Ahmet Doğan - in 1990-2013 the leader of the Movement for Rights and Freedoms (DPS), and a member of the National Assembly. 
It was difficult for Sophronius to name the bird, which in the Polish translation was called the zimorodek 'kingfisher' (Lat. Alcedininae) (Wojciechowski, 2006, 37). Perhaps not knowing this bird from the autopsy, Sophronius decided it would be safe to leave the Greek name (Алкїшни,,$\lambda)$, as the beginning of the fable contains an explanation of what bird it is about, which is necessary to understand the content of

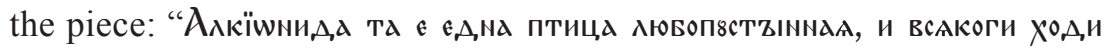
покрай морето, и Храни са, и тамо сноси ғайцата си покрай морето. "” Nowadays - according to the Polish-Bulgarian dictionary (Radeva, 1988, vol. II, 881) - this bird is called земеродно рибарче, and colloquially рибар or риболовец.

The main character of one of the fables is a bird defined by Sophronius мочмъий врань. This name appears only once, and the fable does not contain any content indicating which bird it is, although the lexeme врамь evokes associations with both the crow (врана) and the term jet black, most often referring to the horse's colour (вран). The adjective мочмили may indicate the nocturnal lifestyle of this bird. ${ }^{7}$ It is good, however, that in order to understand the meaning of this fable and the moral flowing from it, the question of the species of its hero-bird is completely indifferent.

It is also difficult to determine what bird is the hero of the fable entitled MАлєшко птичи. The content of this work is not identical with any of Aesop's fables, catalogued by Halm (1852) or Hausrath (1940). ${ }^{8}$ The evolution of its content is probably due to the fact that Sophronius did not use an Ancient Greek source, but a Modern Greek version of fables most likely translated by Joanis Patusas, although there are also other hypotheses regarding the source of the Sophronius translation (Walczak-

${ }^{6}$ In Polish translation: "Zimorodek to ptak lubiący samotność i przebywający stale na morzu. Powiadają o nim, że strzegąc się ludzkich sideł, gnieździ się na urwiskach nadmorskich." ("The Kingfisher is a bird that likes solitude and is always at sea. It is said that, guarding against human traps, it nests on coastal bluffs" [Wojciechowski, 2006, 37]).

${ }^{7}$ In the Polish translation, there is talk of a jackdaw ( $\left.k a w k a\right)$ whose name in modern Bulgarian is чавка. The compendia in the field of ornithology do not mention any of the features of the jackdaw that would allow it to be defined as a nocturnal animal (Richarz, Puchta, 2006, 346; Kruszewicz, 2007, 272).

${ }^{8}$ Perhaps it is a fairy tale translated into Polish entitled Kwiczol (in Halma's catalog no. 194, in Hausrath's 88). 
-Mikołajczakowa, 2009, 15). The translator's decision to call the main character simply "a little bird" resulted from the content of the fable, in which it is only important that a small creature is sent to the cage, or captivity, which could not do much harm to a human.

In the translations of Sophronius, fish most often appear under the general name of рига. Only the common fish in the Black Sea смари,, a, from the broadsword family got its species name, taken, of course, from Greek.

Among the reptiles and amphibians that are the heroes of fables, the most common is жАБג, called in the same (or very similar) way throughout the Slavic area. The name comes from the Proto-Slavic *gēba , it can also be proved to be related to names occurring in the entire Indo-European language family (Георгиев, 1971, 519-520). The lexeme жаба was also used to form the descriptive name of the turtle: костана жава. The name костена / костяна жаба is still used in a wide range of dialects of central and northern Bulgaria (including in the vicinity of the cities of Elena, Velingrad, Teteven), it has also been preserved in the language of Banack Bulgarians, i.e. descendants of $18^{\text {th }}$-century emigrants professing Catholicism. Today, the name костенурка is used. In the form of костянурка it is already noted in the Gerov dictionary, citing various dialectal names: желва, желка, жьлва, костяна жаба, костенуша, коруба жаба (Геров, 1897, 402).

The heroine of several fairy tales is the viper, which Sophronius names in two ways - with the Slavic lexeme змия (with two spellings: sмил or

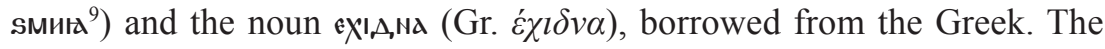
Greek borrowing of ехидна, already recorded in the oldest monuments of Slavic literature (Suprasl Codex, Manasseh Chronicle translated from the beginning of the $14^{\text {th }}$ century), today is considered an obsolete, marked, poetic name ${ }^{10}$ (Георгиев, 1971, 515-516). Unfortunately, the content of fables, characters of which are vipers does not contain any hints as to the reasons why the Bulgarian translator decided to choose one of the synonyms indicated.

\footnotetext{
${ }^{9}$ This way of writing was taken over from the Old Church Slavonic literature; it appears in the Codex Zographensis, Codex Marianus, Sava's Book and Codex Suprasliensis (Георгиев, 1971, 647).

${ }^{10}$ In modern zoological terminology, the word ехидна refers to the echidna.
} 
However, there should not be any hesitations when using the name $\kappa$ коко, ,икь, although this animal has never been found in the European fauna.

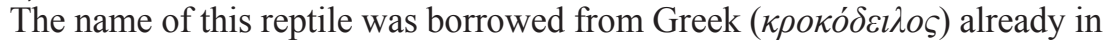
the Old Slavonic period (it was used, for example, by John the Exarch). No wonder, since the crocodile appears in the text of the Old Testament (Job 40:25, Ezek. 29: 3, Ezek. 32,2). The name of the crab caused Sophronius a little more of a problem. Knowing that marine fauna is not well known among Bulgarians, Sophronius appealed to the imagination of the audience and called the crab опхкь ракь, thus pointing to the peculiar way that this crustacean moved. Even today, the names of sea animals are not very varied in Bulgarian, hence although shrimps, crawfish, langoustines, lobsters, crabs and other rare seafood appear in the menu of some restaurants, they come under the collective name of paun and it only depends on the waiter's competence whether he is able to explain to customers what type of shrimps it is about in a given case. In Gerov's dictionary we can find the entry крабарь, but his vague definition of 'животина нъкаква' does not allow us to state that it is definitely a crab (Геров, 1897, 407). This name was not accepted permanently and modern dictionaries do not mention either the *крабар or *краб lexemes, and the Polish-Bulgarian dictionary translates the name krab as морски рак (Radeva, 1988, vol. I, 239).

On the other hand, сюнгер - сюнгерь (by Sophronius) retained its place in the lexical resources of the Bulgarian language - the name of a sea sponge (Spongia officinale), having its source in Greek, which found its way into Bulgarian via Turkish (Turkish sünger).

The name of the scorpion, taken from Greek already in the Old Bulgarian period and recorded in the oldest monuments (Codes: Suprasl, Zograf, Marian), was not a problem either. In the form скорпия (that is, in the form suggested by Sophronius - ккорпіа) we can find it in Gerov's dictionary and dialects from the vicinity of Vratsa (Рачева, Тодоров, 2002, 786).

Among the insects in Aesop's fables, there are only those commonly known, i.e. flies (мухи), fleas (болха), ants (мрави) and field cricket (щурець). Sophronius called the cicada less known in Bulgaria as the onomatopoeic expression чичика - it is actually onomatopoeic Greekism, having its prototype in Greek $\tau \zeta i \tau \zeta i \kappa \alpha \varsigma$. The character of one of the fables is a hornet, an insect with a dozen or so dialectal versions of the name in Bulgarian (Рачева, Тодоров, 2010, 534-535). Of these, the literary Bulgarian 
has chosen the name of стьршел. Sophronius clearly hesitated as to the correctness of the name of this insect, because in the text of the fable we find both the version with the $s$ and sht: сторшиль and чоршихь.

The most problematic, however, was the name of a beetle unknown to Bulgarians - the scarab. As the content of the fairy tale $0_{\rho \in \lambda b}$ и кAN-0.dpb refers to the peculiar habit of scarabs, which is rolling balls with fertilizer, the name of this beetle could not be avoided. Sophronius used the Greek name kaN.o.Aps, perhaps recognizing that the description of the surprising behaviour of the fable hero is enough for the reader to conclude that it is an alien, unknown to Bulgarian fauna. In modern Bulgarian, the lexeme кантар means only a certain type of weight, an old unit of weight or a weight corresponding to this unit.

It is also worth paying attention to the animalism червіл (со. червей), which means an unknown small-size creature living in the ground. It is difficult to discern the name of any specific animal in this lexeme - it seems that Sophronius used it in the same sense as the word robak ('worm') is used in colloquial Polish. The dictionaries of the modern Bulgarian language agree, however, that under the name червей there may be an earthworm or an immature form of any insect, i.e. a larva.

Perhaps the most problematic animal name for several generations of Bulgarian authors was the name of a snail. Sophronius decided to use the name салангодь, borrowed from the Turkish language (Turkish salyangoz), but in the title he added an explanation: саламгобZ, сирєчь пвжовцZы. Thus, the Turkish borrowing was explained with one of the many dialectal names functioning in a limited area. We will not find any of these names in the dictionary of rare and obsolete words edited by Stefan Ilchev. On the other hand, the form пужел is noted, with the qualifier "dialectal" and examples from the work of Pancho Mikhailov, a writer born in the city of Shtip (now North Macedonia), thus using Western language. In Nayden Gerov's dictionary we find a snail in several entries under several names. In volume IV there are пужель and пужерь reminiscent of one of the names used by Sophronius (Геров, 1901). Unfortunately, these names are provided without any explanation. Volume III contains the names охлё, охлёвчя, охльвъ, close to the modern animalism of охлюв (Геров, 1897, 436), but the author of the dictionary refers readers to the entry лигавець (v. Bulgarian лигавина - 'mucus'). 
The entry лигавеuь is extremely extensive, it collects several dozen different synonyms referring to two species of snails: Helix and Limax (Геров, 1897, 22-23). Helix snails were named in Bulgarian dialects in various ways: бабуръ, бахаль, бохлё, бохлёвъ, гугу-петръ, гулшёкъ, жембаль, жюжель, лигавничя, лиговець, лонбй, мелчё, мелчёвъ, охлёвъ, пасмолечь, пасочя, пахаль, пижёкъ, пижёвякъ, пиши-рогъ, паужковъ, плужякъ, плужькъ, плужекъ, пльжець, пльжковъ, пльжякъ, прьжлокь, прьжяйка, пльзекъ, пужимусь, пужель, пужь, роглё, роглёвець, роглець, рожко, рожковець, рожковь, салякь, слимакъ, слимукъ, слишакъ, сльменъ, слюмакъ, слюнакъ, смилякъ, стригоръ, тодоръ, улешка, улешь, уфлешка, шелянгосъ, шялякъ. Shell-less snails of the Limex species had much fewer terms (Gerov notes "merely" 9), often repeating the name from the previous group preceded by the epithet гол ('naked'): голякъ, голь бабуръ, голь охлёвъ, голь пужякъ, голь руяколь, водна прьжялка, дивъ пльжекъ, циганскый, зьмскый бухыръ.

Fifty four dialectal names of the Helix species make us aware of the difficulties the codifiers of the Bulgarian lexicon had to deal with in relation to the names of animals. Choosing one of the many animalisms was tantamount to imposing it on all Bulgarian speakers, regardless of their individual habits derived from folk dialects. Even if the names of other animals were less differentiated, the creation of a uniform dictionary of animalisms must have been a lengthy process.

Sophronius was assigned the role of the precursor of this process. The translator of Aesop's fables did not hide the difficulties associated with it - in embarrassing situations he resorted to several translation techniques: he published an explanation of what animal it was about, described the features of a little-known animal, or, on the contrary, avoiding specifics, he generalized the name using the terms "little bird", "little fish". In some cases, it allowed the reader to choose the name on his/her own, giving

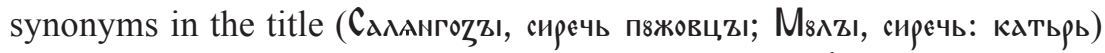
in others he used a descriptive name ("мочна мышка фарковита"). Noteworthy is the use of animisms borrowed from Greek or Turkish language, which proves the author's awareness that these names managed to displace the native vocabulary from human consciousness (v. e.g. камила). The translator's effort was not in vain, since most of the names he used are still used today. The continuators of Sophronius' work followed the same lead, 
using similar techniques in their translations. Thanks to their works, the literary Bulgarian language was enriched with new names, absent in the lexicon of Sophronius.

\section{References}

Boryś, W. (2008). Slownik etymologiczny języka polskiego. Kraków: Wydawnictwo Literackie.

Halm, C. (red.). (1852). Fabulae Aesopicae collectae. Leipzig: Teubner.

Hausrath, A. (red.). (1940). Corpus fabularum Aesopicarum. Leipzig: Bibliotheca Scriptorum Graecorum et Romanorum Teubneriana, vol. I/1.

Kruszewicz, A. (2007). Ptaki Polski. Warszawa: Oficyna Wydawnicza Multico.

Radeva, S. (1988). Podręczny stownik polsko-butgarski z suplementem, vol. I-II. Warszawa: Wiedza Powszechna.

Richarz, K., Puchta, A. (2006). Ptaki. Przewodnik. Warszawa: Muza S.A.

Szerszunowicz, J. (2014). Definicja kognitywna jako skladnik opisu leksykograficznego zwiąków frazeologicznych z komponentem animalistycznym. In: Životinje u frazeološkom ruhu: zbornik radova s međunarodnoga znanstvenog skupa Animalistički frazemi u slavenskim jezicima održanog 21. i 22. III. 2014. na Filozofskom fakultetu Sveučilišta u Zagrebu. Ur. I. Vidović Bolt. Zagreb: Filozofski fakultet Sveučilišta u Zagrebu. www.animalistcki-frazemi.eu>images>zbornik_radova. 18.10.2020.

Walczak-Mikołajczakowa, M. (2009). Butgarski Ezop. Poznań: Wydawnictwo Naukowe UAM.

Wojciechowski, M. (przeł.). (2006). Ezop i inni. Wielka księga bajek greckich. Kraków: Wydawnictwo WAM.

Александрова, Р. (1993). За наименованието на животното таралеж. "Език и литература" № 5-6, pp. 76-78.

Балкански, Т., Цанков, К. (2010). Енииикопедия на българската ономастика. Велико Търново: Фабер.

Бояджиев, Т. (1986). Българска лексикология. София: Наука и изкуство.

Георгиев, В. (ред.). (1971). Български етимологичен речник, vol. 1. София: Издателство на БАН.

Георгиев, В. (ред.). (1986). Български етимологичен речник, vol. 3. София: Издателство на БАН.

Геров, Н. (1895-1904). Ръчникъ на блъгарскый языкъ с тлъкуване на рбчи-ты на блъгарскы и на рускы, vol. I (1895), vol. II (1897), vol. III (1899), vol. IV (1901), vol. V (1904). Пловдив: Дружествена печатница "Съгласие".

Илчев, С. (ред.). (1974). Речник на редки, остарели и диалектни думи в литературата ни от XIX век. София: Издателство на БАН. 
Нанкинов, Д. (2010). Древнобългарски имена на птиците. София: Издателство ETO.

Недкова, Е. (2005). Националноспецифични образи в български и сръбски фразеологизми с компоненти зооними за експресивно назоваване на човешки качества. "Научни трудове на Русенски Университет" vol. 44, ser. 6.2, Русе, pp. 44-48.

Ничев, А. (1961). Български превод на Езоп от 1812 г. "Език и литертура" vol. 6, pp. 58-66.

Рачева, М., Тодоров, Т. (ред.). (2002). Български етимологичен речник, vol. VI. София: Академично издателство "Проф. Марин Дринов."

Рачева, М., Тодоров, Т. (ред.). (2010). Български етимологичен речник, vol. VII. София: Академично издателство "Проф. Марин Дринов."

Радев, И. (2007). История на българската литература през Възраждането. Велико Търново: Абагар.

Вълчев, Б. (2009). От историята на българския книжовен език към теорията на книжовните езици. София: Оксиарт.

Зидарова, В. (1997). За някои зооморфни метафори в съвременния български език. „Научни трудове ПУ “Паисий Хилендарски” vol. XXXV, № 1, pp. 99-104.

[Aleksandrova, R. (1993). Za naimenovaniyeto na zhivotnoto taralezh. "Ezik i literatura” № 5-6, pp. 76-78.

Balkanski, T., Tsankov, K. (2010). Enciklopediya na balgarskata onomastika. Veliko Tarnovo: Faber.

Boyadzhiev, T. (1986). Balgarskata leksikologiya. Sofiya: Nauka i izkustvo.

Georgiev, V. (red.). (1971). Balgarski etimologichen rechnik, vol. 1. Sofiya: Izdatelstvo na BAN.

Georgiev, V. (red.). (1986). Balgarski etimologichen rechnik, vol. 3. Sofiya: Izdatelstvo na BAN.

Gerov, N. (1895-1904). Rechnik na balgarskiy yazik s tlakuvane na rechi-ty na blagarsky i na rusky, vol. I (1895), vol. II (1897), vol. III (1899), vol. IV (1901), vol. V (1904). Plovdiv: Druzhestvena pechatnitsa "Saglasiye."

Ilchev, S. (red.). (1974). Rechnik na redki, ostareli i dialektni dumi v literaturata ni ot $X I X$ vek. Sofiya: Izdatelstvo na BAN.

Nankinov, D. (2010). Drevnobalgarski imena na pticite. Sofiya: Izdatelstvo ETO.

Nedkova, E. (2005). Nacionalnospecifichni obrazi v balgarski i srabski frazeologizmi s omponenti zoonimi za ekspresivno nazovavane na choveshki kachestva. "Nauchni trudove na Rusenski Universitet" vol. 44, ser. 6.2, Ruse, pp. 44-48.

Nichev, A. (1961). Balgarski prevod na Ezop ot 1912 g. "Ezik i literatura" vol. 6, pp. 58-66.

Racheva, M., Todorov, T. (red.). (2002). Balgarski etimologichen rechnik, vol. VI. Sofiya: Akademichno izdatelstvo "Prof. Marin Drinov."

Racheva, M., Todorov, T. (red.). (2010). Balgarski etimologichen rechnik, vol. VII. Sofiya: Akademichno izdatelstvo "Prof. Marin Drinov."

Radev, I. (2007). Istoriya na balgarskata literatura prez Vazrazhdaneto. Veliko Tarnovo: Abagar. 
Valchev, B. (2009). Ot istoriyata na balgarskiya knizhoven ezik kam teoriyata na knizhovnite ezici. Sofiya: Oksiart.

Zidarova, V. (1997). Za nyakoi zoomorfni metafori v savremenniya balgarski ezik. "Nauchni trudove PU 'Paisiy Hilendarski’” vol. XXXV, № 1, pp. 99-104]. 